\title{
Strengthen First-Computer-Based Computer-Based Student Programming Skills
}

\author{
B. O. Ogunlade, S. B. Bahago, and A. S. Ogunmodede
}

\section{ABSTRACT}

Programming is a difficult task that requires the creation of new ideas, thinking, and creative skills. The study, therefore, aimed to strengthen BASIC's programming skills to guide and mentor students at Veritas University Abuja, Nigeria. The researchers assessed students' interest in computer usage and gender differences. The study adopted the group that controls most, the experimental structure. 100 and 200 level undergraduate students are selected on a well-equipped computer and existing Computer lecturers are deliberately chosen at the University. Two non-static classes with 50 students are periodically assigned to the Experimental (25) and Control (25) groups. The treatment lasted six weeks. The instruments used were descendants of Undergraduate Students 'graduates towards the Question nailing Usage Questionnaire and Programming Skills Performance with the reliable coefficient of 0.78 and 0.88 , respectively. Data were obtained from covariance analysis, with a significance level of 0.05 . More than half of the participants were female $(62 \%)$. Treatment had a significant impact on students in the language of BASIC Programming $F=36.385 ; p<0.05$. Also, students' interest in computer use has little effect on students $F=2.109 ; p>0.05$. Performance BASIC programming skills $F=0.021 ; p>0.05$. A computer-based teaching strategy has been developed to improve student performance and revitalize student interest in computer use and programming at Veritas University Abuja. Computer educators should adopt a computerbased teaching strategy in teaching computer programming in ICT education to enhance students' writing skills. Also, the design emphasizes the need to continue to use new techniques such as computer teaching techniques to simplify and improve the delivery of instruction.

Keywords: Basic Program, Computer-Based Skills, Guidance and Counseling, Teaching Strategy.

\section{INTRODUCTION}

Human, capital, and social development are important to each nation, depending on the education provided. It is in this context, therefore, that the standards of education are structured and therefore form the basis for growth and development in education. The University education program in Nigeria is the highest level of academic achievement. University education has an average of four years, regardless of academic study.

Emphasis on students' undergraduate Guidance and Counseling skills is related to student development around. This program requires different response needs, providing benefits to students while caring for their psychological, emotional, social, psychological, and technical needs. Expectations of successful students can be relieved of stress-induced learning situations instead of self-defense, adjustment, improvement, and innovation. However,
Published Online: December 3, 2021

ISSN: $2736-4534$

DOI : 10.24018/ejedu.2021.2.6.2.207

\section{B. O. Ogunlade*}

Educational Technology Department, Bamidele Olumilua University of Education, Science and Technology, Ikere-Ekiti, Nigeria.

Orcid ID 0000-0002-1029-3383

ogunlade.bamidele1@bouesti.edu.ng S. B. Bahago

Educational Foundation Department Veritas University, Abuja samufutuk@gmail.com

A. S. Ogunmodede

Educational Technology Department, Bamidele Olumilua University of Education, Science and Technology, Ikere-Ekiti,.Nigeria.

ogunmodede.aderemi@bouesti.edu.ng

*Corresponding Author

guidance and counseling should be accountable, wellplanned, and focused on technical goals. That is a lifelong learning experience that aims to strengthen students' level of ability to lay the foundation for critical thinking by focusing on appropriate learning, self-awareness, and life skills (Owuamanam, 2005). Guidance and advice play an important role in the future work of Nigeria and its youth. For this program to be comprehensive, it must also apply to all aspects of students through technological advances in the 21st century, not just to maintain the status quo (Maduewesi \& Ezeoba, 2010). This must be met with success and efficiency. It is a phase of transformation where students are introduced to programming skills with a teaching program in a Computer program and so on.

Therefore, they should also contribute to making a significant contribution to the educational growth of developing countries by generating appropriate capacity in line with the needs of the education sector, society, and the world at large (Vijay, 2017). This can be achieved when 
students have the opportunity to connect with ICT resources and do hands-on activities (Ogunlade \& Akhigbe, 2016). The Nigerian Government as contained in the National Education Policy, FGN (2013) highlighted the main objectives of educational opportunities to:

- acquire the necessary knowledge, skills, and pride for the betterment of yourself and the nation.

- build a solid foundation for further education and training.

- develop the ability to ask questions, think, and act logically

- identify individual talents and develop them

- lays the foundation for technological and industrial development.

In light of the above, proper education for university students (Guidance and Counseling) is regarded as a basic tool for successful child development and community development. In this context, therefore, there is a great need to build computer programming skills through strategic teaching communities in all educational institutions, and especially among younger generations of teachers. These learning communities teach sustainable development, promote shared commitment, and support the alignment of individual, group, school, and school goals. Each member is responsible for each other to achieve the shared goals of the school and school program and to work transparently, real-time settings that support their development. In this regard, there is a growing need for advanced computer literacy as a tool for promoting high-quality human resources for the sustainable development of national education as emphasized by (UNESCO, 2014). It is consistent with this that schools at all levels offer some ICT and computer-related courses and thus utilize the teaching and learning capabilities of computerized human resource management and building program in schools.

However, computer programming is the universal language of our planet and basic digital learning contains various instructions that users give to a computer to perform any given task. It is a set of words, symbols, and codes used to write a computer program. The process of writing these commands (system) is called a system. Program language can now be defined as a set of rules given to a computer to perform a given task. Computer programming language can be defined as the process by which a computer program can produce the expected or desired (output) result. Programs are a set of computergenerated commands to perform a task and are written in a programming language.

Programming involves the ability to solve a problem, which means that one of the learning outcomes is the ability to solve problems, and also if the problem is large, the ability to divide the problem into problems and create a centralized solution. In addition, the learner gains the ability to make practical, readable, and attractive solutions. In addition, programming knowledge helps students gain and gain control over a variety of technological gadgets and establishes connections with some of the deepest perspectives of various fields such as education, science, engineering, mathematics, and intelligence, and psychology.
There is no doubt that learning a computer program at an undergraduate course is beneficial for all students, at least in their daily lives. The benefits of learning the program help young teachers discover the benefits of thinking, processing, and communication. These benefits can support the acquisition, development, and improvement of 21st-century skills among student (Govender et al., 2014).

Knowledge of computer programming skills among others enables students to solve tasks that require strategic thinking, critical thinking, comprehension, and creativity. These activities seem to attract the most students and better prepare them to take their place in the knowledge society. Many researchers believe that being involved in programs not only enables students to gain knowledge of the program, but also has a powerful effect on promoting their performance of higher thinking (Chang et al., 2012). The ability to understand and use grammar is an important skill that students can acquire.

Computer programming skills, an integral part of ICT, are a major driver of the 21 st century that has made life easier since its inception. Progress recorded with significant progress in all aspects of human activity has had a profound effect on the use of computer technology in school counseling programs. With the increasing and frequent changes in the curriculum to meet the needs of 21 st-century students, there is a growing need for the use of a computer program in a variety of ways. Therefore, Government agencies, educational programs, researchers, school leaders, and educators see the teaching strategy as essential to the development of the university education curriculum (Chao, 2016). The important role that technology plays in education provides leadership and mentors, students, and other educational stakeholders the opportunity to develop meaningful learning knowledge, based on the use and use of a computer.

The installation of computer programs for teacher training at Veritas University, Abuja was due to the need to acquire the skills required to use computers where, students are expected to learn to use word processing programs to plan, perform simple and logical calculations and use this knowledge to transform human resource and education counseling skills (Olowoyeye \& Ogunlade, 2015). The launch and implementation of this article in many countries around the world took place due to the announcement of policy and the need to address the trends of computer technology and education (Ramlogan et al, 2014). Computer programming is therefore a topic designed to allow students to understand computer performance, usage, and limitations and to provide an opportunity to study modern methods of information processing.

In other words, as a learning tool, the teaching strategy draws the attention of students and this often creates the joy of learning (Bukaliya, 2012). He further emphasized that a Computer is a multidisciplinary tool that stores, uses, and retrieves information about students' participation in teaching activities to enhance their learning, as well as helping them to solve complex problems in counseling to improve their comprehension and deceptive skills.

Govender et al. (2014) suggest that some of the skills 
required in a writing process are not explicitly taught, so problem-solving teaching, one of the skills required, should not only include presence and problem solving but should also include problem-solving teaching. The writing process of the program requires in-depth reading skills and awareness by understanding how the problem of counseling can be solved successfully. For this reason, program writing involves reviewing decisions and actions that further improve program quality and produce alternatives that can lead to clear results (Kpolovie et al., 2014).

Finally, the importance of the program is considered to be one of the most important factors in 21st Century Skills, A major challenge is how to allow students to start programming at an early age as experts Katai and Toth (2010) believe that programs are learned early. Some of the languages that enable students to acquire these skills are at the level of beginners among others including BASIC. QB language teaching and learning lies in the user interface, which provides immediate feedback on syntax errors and operating time errors. Like other formal programming languages such as PASCAL and FORTRAN, etc., it is a process-oriented language, which uses a problem-solving process and uses. To achieve these goals and the successful acquisition of programming skills and knowledge as a school subject, it must be successfully taught by qualified computer educators (Ogunlade, 2014).

Despite the growing use of technology in everyday life, there is a continuing gender gap in girls' access to technology compared to boys. They also get less exposure to technology-related activities compared to boys, and this starts early in growth (Kay, 2012). It has been reported in many computer science studies that the enrolment of women in computer science in programming was very low (Govender et al., 2014). This may be due to women's worse attitude towards computers than men (Chang et al., 2021). Similarly, the results of one study showed that the status of women in the program was significantly lower than that of men in contrast to the results of studies conducted Yildirim and Kaban (2010) that favor higher performance for women.

Computers are generally accepted as modern tools that enable teachers to choose teaching methods that will increase students' interest and participation in learning (Ogunlade, 2019). Therefore, the National Education Policy (FRN, 2013) sets out guidelines for procedures and functions in the use of computer technology at different levels of learning in school subjects in the early years of study, and this contributes to the use of the ComputerBased Teaching Strategy (CBTS). ICT and technical methods of teaching, learning, and counseling in schools, which are to promote, co-ordinate and support classroom learning activities and counseling activities.

CBTS is a systematic way of continuous learning among students, due to its powerful, clear, non-textual methods and methods of capturing and presenting facts and facts that help students use ICT-based technology and computer content in interaction and learning. It is an educational strategy that involves the use of a computer to bring advice and learning content (Govender et al., 2014).

CBTS has been a standard teaching method used in the classroom and beyond to deliver education (Ramlogan et $a l ., 2014)$. In the classroom, independent learning using the CBT promotes independence and the ability to take the necessary time to manage the content presented. This type of reading allows students to re-play on the computer as often as possible to understand its content. Specifically, the use of computers, video streams, or video-web communications includes an educational curriculum for various disciplines that do not leave behind computer programs. From the students' point of view, research has shown that a computer can be more effective than text to increase their satisfaction and motivation during the learning process (Sáez-López et al., 2016).

The CBTS method differs from investigated or integrated learning as the computer is observed in the classroom during the lesson, not at home. This means that the teacher has the right content to be presented on the computer, and different videos can be made at different levels, tailoring to the needs of the students. It also changes the role of the teacher to become a facilitator or trainer, able to roam the classroom watching the various videos used as students complete the given instructions (Michael \& Heather, 2014).

Teacher-based programs allow specially selected content to be presented to individuals or groups of students as needed and ensure that the teacher plans and delivers appropriate content to a range of needs in the classroom. Chang (2012) found that using computer-based instruction offers many benefits, such as increased student freedom and reduced dependence on adult support, consistent student education, and minimal computer-assisted adult training-based education.

Computer-based instructions appear to be very motivating for Guidance and Counselling students as they allow students to view real-life scenes and scenes, see the sequence of movements, and listen to the narrative. Therefore, this research often reinforces the basic skills of organizing university graduates through an online teaching strategy in guidance and counseling.

\section{A. Problem Statement}

The computer program is incorporated into the university's undergraduate curriculum to expose students to the necessary problem-solving skills in producing competitive people around the world and thus to develop a high level of student thinking among others through guidance and counseling. Learning programs is a difficult task because programs require the development of new ideas, thinking, and creative skills in problem-solving. Experience shows that students see learning computer programs as a difficult, unpleasant, and tedious task in their work. This has often prompted researchers to try to develop cluster-based environments to reduce the burden on students to develop computer programs.

One of the biggest challenges facing teachers and education professionals in the field of computer education is how to make a computer program attractive and interesting for students to meet global competition that includes students' ability to demonstrate sufficient skills needed for learners' counseling, mentoring, and the ability to write simple BASIC program code. This requires the use 
of different techniques to make it interesting, friendly, and meaningful to guidance and counseling students. Therefore, this study aims to develop and strengthen the programming skills of undergraduate guidance and counseling students using BASIC computer programming and teaching strategies.

\section{B. Hypotheses Guided the Study}

The following hypotheses were rated at a significance level of 0.05 :

1. $\mathrm{Ho}_{1}$ : There is no significant therapeutic impact on the performance of Guidance and Counseling students in the basic language of programming skills.

2. $\mathrm{Ho}_{2}$ : There is no significant impact on Guidance and Counseling students' interest in computer use in student performance in the primary language of the program.

3. $\mathrm{Ho}_{3}$ : There is no significant effect of gender-based communication on the functioning of the BASIC computer programming language.

\section{Methodology AND DESCRIPTION OF THE SAMPLES}

The research design adopted a non-judgmental, quasiexperimental control group. A staple in the Study is the Computer-based Instructional Strategy, students' interest in computer use in three (3) categories (low, standard, and high), and student performance assessments in the language of BASIC programs. The study population includes all students of the Veritas University Faculty of Education, Abuja. While the sample size has 50 students of three departments in the faculty. The sampling process is intended to be used to select the university that participated in the study. Optional university options are the availability of a well-equipped computer laboratory and the school's willingness to participate in research.

The random sampling process was adopted for selecting study participants from the control and experimentation groups. The materials used for this study are students' interest in computer-based questionnaires, ComputerBased Teaching, and Student Performance Assessment in BASIC Programming Skills. The tool was certified by computer education lecturers and experts in the field of Educational Technology and Counselling unit at Veritas University Abuja on content and performance. While the reliability of the instruments is established; the interest rate for undergraduate Students towards Computer Usage Questionnaire and Programming Skills Performance Test stands at 0.78 and 0.88 respectively. The baseline data for Covariance Analysis (ANCOVA) was used to test and obtain outcomes for groups at a significance level of 0.05 .

\section{DATA ANALYSIS OF RESUltS}

Ho1: There is no significant therapeutic impact on the performance of Guidance and Counseling students in the basic language of programming skills

TABLE I: ANALYSIS OF COVARIANCE (ANCOVA) SHOWING THE EFFECT OF TREATMENT ON STUDENTS’ IN BASIC PROGRAMMING LANGUAGE

\begin{tabular}{|c|c|c|c|c|c|c|}
\hline Source & $\begin{array}{c}\text { Type III Sum of } \\
\text { Squares }\end{array}$ & Df & Mean Square & $\mathrm{F}$ & Sig. & $\begin{array}{c}\text { Partial Eta } \\
\text { Squared }\end{array}$ \\
\hline Corrected Model & $205.504^{\mathrm{a}}$ & 7 & 29.358 & 12.269 & 0.000 & 0.672 \\
\hline Intercept & 200.082 & 1 & 200.082 & 83.620 & 0.000 & 0.666 \\
\hline Pretest & 13.335 & 1 & 13.335 & 6.6531 & 0.023 & 0.117 \\
\hline Treatment & 87.061 & 1 & 87.061 & 36.385 & $0.000 *$ & 0.464 \\
\hline Gender & 0.933 & 1 & 0.933 & 0.390 & 0.536 & 0.009 \\
\hline Interest & 5.046 & 1 & 5.046 & 2.109 & 0.154 & 0.048 \\
\hline Treatment $*$ Gender & 30.755 & 1 & 30.755 & 12.854 & 0.001 & 0.234 \\
\hline Treatment $*$ Interest & 4.820 & 1 & 4.820 & 2.014 & 0.163 & 0.046 \\
\hline Gender $*$ Interest & 2.328 & 1 & 2.328 & 0.973 & 0.330 & 0.023 \\
\hline $\begin{array}{c}\text { Treatment } * \text { Gender } * \\
\text { Interest }\end{array}$ & 0.000 & 0 & . & . & . & 0.000 \\
\hline Error & 100.496 & 42 & 2.393 & & & \\
\hline Total & 6804.000 & 50 & & & & \\
\hline Corrected Total & 306.000 & 49 & & & & \\
\hline
\end{tabular}

R Squared $=0.672$ (Adjusted R Squared $=0.617$ )

Table I showed that treatment has a significant effect on the performance of Guidance and Counseling students in the language of BASIC programs $\mathrm{F}=36.385 ; \mathrm{p}<0.05$. The null hypothesis is therefore rejected. The result also showed that the result size is $46.4 \%$. A table of moderate treatment modalities showed that Guidance and Counseling students exposed to an online teaching strategy had significantly higher scores compared to those in control. This means that a computer-based teaching strategy increases the vulnerability of students.

Ho2: There is no significant therapeutic impact on the Guidance and Counselling interest of 'students' in basic computer systems. 
TABLE II: COVARIANCE ANALYSIS SHOWING GUIDANCE AND COUNSELLING STUDENTS’ INTEREST IN COMPUTER USE IN THE BASIC LANGUAGE OF THE STUDENT PROGRAM

\begin{tabular}{|c|c|c|c|c|c|c|}
\hline Source & Type III Sum of Squares & Df & Mean Square & $\mathrm{F}$ & Sig. & Partial Eta Squared \\
\hline Corrected Model & 144.011 & 7 & 22.144 & 5.191 & 0.000 & 0.376 \\
\hline Intercept & 315.886 & 1 & 315.886 & 74.324 & 0.000 & 0.567 \\
\hline Preperformance & 2.414 & 1 & 2.414 & 0.566 & 0.456 & 0.013 \\
\hline Treatment & 63.345 & 1 & 63.345 & 14.849 & $0.000^{*}$ & 0.261 \\
\hline Gender & 19.897 & 1 & 19.897 & 4.664 & $0.037 *$ & 0.100 \\
\hline Interest & 0.088 & 1 & 0.088 & 0.021 & 0.887 & 0.231 \\
\hline Treatment $*$ Gender & 0.002 & 1 & 0.002 & 0.000 & 0.984 & 0.000 \\
\hline Treatment $*$ Interest & 3.664 & 1 & 3.664 & 0.859 & 0.359 & 0.020 \\
\hline Gender * Interest & 0.418 & 1 & 0.418 & 0.098 & 0.756 & 0.002 \\
\hline Treatment $*$ Gender $*$ Interest & 0.000 & 0 & . & . & . & 0.000 \\
\hline Error & 167.169 & 42 & 4.201 & & & \\
\hline Total & 6445.000 & 50 & & & & \\
\hline Corrected Total & 321.180 & 49 & & & & \\
\hline
\end{tabular}

a. R Squared $=0.432$ (Adjusted R Squared $=0.345$ )

Table II shows that interest has a significant impact on the performance of Guidance and Counseling students $F$ $=0.21 ; \mathrm{p}<0.05$. The null hypothesis is therefore rejected. The result also showed that the result size is $23.1 \%$. The table of moderate treatment modalities shows that students exposed to an online teaching strategy have significantly higher scores compared to administrators.

Ho3: No significant effect on gender-based communication on BASIC computer programming language

TABLE III: COVARIANCE ANALYSIS (ANCOVA) SHOWS THE COLLABORATIVE PERFORMANCE OF TREATMENT AND GENDER ON STUDENTS' COMPUTER PPERFORMANCE IN BASIC PROGRAMMING LANGUAGE

\begin{tabular}{|c|c|c|c|c|c|c|}
\hline Source & $\begin{array}{c}\text { Type III Sum of } \\
\text { Squares }\end{array}$ & Df & Mean Square & $\mathrm{F}$ & Sig. & $\begin{array}{c}\text { Partial Eta } \\
\text { Squared }\end{array}$ \\
\hline Corrected Model & 201.524 & 7 & 26.347 & 12.269 & 0.000 & 0.572 \\
\hline Intercept & 198.082 & 1 & 198.082 & 67.520 & 0.000 & 0.466 \\
\hline Preperformance & 13.335 & 1 & 13.335 & 5.573 & 0.023 & 0.117 \\
\hline Treatment & 87.061 & 1 & 87.061 & 36.385 & $0.000^{*}$ & 0.464 \\
\hline Gender & 0.933 & 1 & .933 & 0.355 & 0.536 & 0.009 \\
\hline Interest & 5.046 & 1 & 5.046 & 2.109 & 0.154 & 0.048 \\
\hline Treatment $*$ Gender & 20.641 & 1 & 20.641 & 10.678 & 0.001 & 0.234 \\
\hline Treatment $*$ Interest & 4.820 & 1 & 4.820 & 2.014 & 0.163 & 0.046 \\
\hline Gender * Interest & 2.328 & 1 & 2.328 & 0.973 & 0.330 & 0.023 \\
\hline Treatment $*$ Gender $*$ Interest & 0.000 & 0 & . & . & . & 0.000 \\
\hline Error & 101.396 & 42 & 2.393 & & & \\
\hline Total & 5804.000 & 50 & & & & \\
\hline Corrected Total & 306.000 & 49 & & & & \\
\hline
\end{tabular}

Table III also showed that gender has no significant effect on student performance $\mathrm{F}=0.35 ; \mathrm{p}>0.05$; So a vain gender-based hypothesis is therefore not rejected. This means that students' gender does not have a significant impact on their performance.

\section{DISCUSSION OF FINDINGS}

The results showed that the treatment had a significant impact on the performance of Guidance and Counselling students in Computer BASIC Programming Language. The findings revealed that the computer-assisted teaching strategy was more effective than the traditional BASIC program language learning. The effectiveness of the treatment strategy is because it involved and supported students who are both graduates in teaching and applying concepts Kay, (2012) and it also helps them to fully manage their co-counseling activities.
The impact of computer-based teaching strategies on student performance in BASIC programs supports the findings of Barr and Guzdial (2015), Ogunlade, (2019), Akinyemi, (2013), and Taslibeyaz et al., (2017) suggested that an online teaching strategy is a more effective way needed to help students gather information, create new ideas, and organize their knowledge, which can improve their behavior change during and after counseling and learning content.

The level of performance of students in computer-based teaching strategies is because it gives students access to advice anywhere at any time and helps them achieve their own problem-solving. It also allows independent learning of handicrafts. The interest in online strategy supports the accountability theory of learning multimedia based on the assumption that the use of an online teaching strategy will engage students and lead to better and more meaningful learning. The results showed that treatment has a significant impact on the performance of instructional and 
counseling students in learning the language of the BASIC program. This support was found by Akinyemi, (2013) that there is a significant difference in student learning and achievement before and after the launch of the LOGO Instructional Package. The findings of the study revealed that the video-based teaching strategy was effective in improving student success in programs. The use of this strategy has provided students with a richer experience than they had when they were taught using standard teaching methods. It was also supported by Chao, (2016) who held the same view that teaching methods and methods used by teachers play a major role in determining student achievement in any subject at all levels of learning. However, this study contradicts the findings of Kaleliog lu, (2015) who found no significant difference between the acquisition of pre-technical skills of high school students who had studied formal education based on video and general teaching strategies.

Research has shown that gender has no significant effect on students' learning in BASIC programs. This can be attributed to the fact that this treatment approach was appropriate for both men and women as it provides both men and women with equal learning opportunities and the opportunity to actively participate in the learning process. This is an indication that treatment is appropriate for both sexes as it does not show discrimination. This claim was supported by the discovery of Akinyemi, (2013) that gender does not make a significant difference in students' learning in LOGO Programming Language. These findings are also in line with those of Adedoja and Fakokunda (2015) and Oguntunde, (2014) who did not report a significant effect on sex. However, the findings can be clarified that the treatment favors both men and women in terms of the effectiveness of studies in programs. This confirms the discovery of Gambari and Zubairu (2008) and Kaleliog lu, (2015) reported that video-based instruction improves student achievement. The acquisition ensures the implementation of video-based instructions to improve student achievement in the BASIC programming language.

\section{CONCLUSION AND RECOMMENDATIONS}

\section{A. Conclusion}

Based on the findings of this study, therefore, it was proved that a computer-based teaching strategy was developed to improve student performance and aroused students' interest in programming and coding, compared to conventional strategy. It was also established that student and gender treatment has a significant impact on student performance in BASIC programs. The strategy was very effective in communicating facts and demonstrating procedures during counseling and assisting in effective learning where the student could observe complex processes as often as possible.

\section{B. Recommendation}

Following the results of the study findings, it is recommended that:
- Teachers should use an online teaching strategy to teach BASIC computer language lesson concepts to improve student performance, coding.

- ICT educators should be well equipped through workshops, seminars, and computer-assisted instructional delivery services that can stimulate students' interest in higher education.

- The Nigeria Universities Commission should emphasize the need to continue to use new technologies as computerized instruction.

\section{ACKNOWLEDGMENT}

The authors appreciate the cooperation of the staff and students, Faculty of Education especially the department of Guidance and Counseling and ICT unit in Veritas University Abuja, Nigeria for their patient and courage in accepting our treatment, test, and questionnaires during the study.

\section{CONFLICT OF INTEREST}

Authors declare that they do not have any conflict of interest.

\section{REFERENCE}

Adegoke, B. A. (2011). The effect of multimedia education on highschool students Success in Physics. European Journal ofEducation 3 (3), 537-541

Adedoja, G.O., \& Fakokunda J.B. (2015). Gender style and style of understanding as to the determinants of student success. Emerging Talks about the Future of Higher Education in Africa. Babcock University Press.

Akinyemi, A. L. (2013). Development and Implementation of the Graphic Orientation (LOGO) Grammar Orientation Teaching Program a the Ibadan Primary School, Nigeria. University of Ibadan, Ibadan. Unpublished P.hD thesis.

Atovigba, M.V., Vershima, A., Michael, E.I., Jenkeli, E. (2012). Sexual orientation in the performance of students of Nigeria Secondary School in Algebra. Statistics and Statistics Journal 4 (2): 42-44.

Barr, V., \& Guzdial, M. (2015). Counseling for CS teaching, and reading for programming languages. ACM communication, 58 (3), 8-9.

Bukaliya, A.K. (2012). Strikes against the Delivery of Computer Education in High School. Global Teaching and Teaching Journals. http://asoindex.com/journal-articlesabstract?id $=20925$.

Chang, SL, Shieh, R.S., Liu, E.Z.F., Yu, P.T. (2012). Factors influencing the status of women are computers in the computer training program. Turkey Online Journal of Education Technology, 11 (4): 177-187.

Chao, P.Y. (2016). Assessing students' practice of counting, designing, and working to solve problems with the physical system environment. Computers \& Education, 95,202-215.

The Federal Republic of Nigeria. (2013). National education policy. Lagos: NERDC Press.

Gambari, A. I., \& Zubairu, A. A. (2008). Effect of video tutorial package with achievement and retention of primary science among primary school students in Niger State, Nigeria. SSSE Second Annual National Conference, Federal University of Technology,

Govender, I., et al., (2014). Increasing hard work in learning how to plan: to explore the benefits of explicit problem-solving instructions The Journal for Transdisciplinary Research in Southern Africa, 10 (1) July (2014), pp. 187-200.

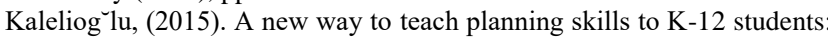
Code.org. Computers in human behavior, 52, 200-210.

Katai, T, \& Toth, L. (2010). Improved technology and technology education for many computer programs. Teaching and Teaching for Teachers, 26, 244-251. 
Kay, R.H. (2012). 'Examining the Use of Video podcasts in Education: Extensive Review of Books. Computers in Human Behavior, 28(3), 820-831.

Kpolovie, P.J., Joe, A., Okoto, T. (2014). Guessing learning success: The role of interest in learning and behavior in school. International Journal of Humanities, Social Science and Education, 1(11), 73100.

Maduewesi, B.U., \& Ezeoba, K.O. (2010). Teacher education in Nigeria in the 21st century: Challenges and prospects. In E. C.luputaife, B. U. Maduewesi \& R. O. Igbo (Eds.), Problems and Challenges in Nigerian Education in the 21st Century (pages 115). New. West and Solomon Publishing Coy Ltd

Michael, B., Horn and Heather Staker (2014) Included: Using Disruptive Innovation to Improve Schools (New York: Jossey Bass,) pg. 31

Ogunlade, B.O., \& Akhigbe, O.J (2016). Social Media: A veritable tool for effective Instructional Delivery in the Tertiary Institution for sustainable National Development. Journal of Nigeria Association for Educational Media and Technology (JEMT), 2(1), 226-238.

Ogunlade, B.O. (2014). Promoting Instructional Technology for Effective and Efficient Academic Performance in Nigerian Schools in Effects of Information Capitalism and Globalization on Teaching and Learning. IGI Global Publication. U.S.A, 48-60.

Ogunlade, B.O. (2019) Instructional Technology an Effective Panacea for Dynamic Education Transformation in Learning: Disseminating Tools for Learning. IGI Global Publication U.S.A, 127-137.

Oguntunde, S.A. (2014). Development of computer-based teaching technology at Ibadan Graduate Learning Program [Unpublished Ph.D. Thesis]. University of Ibadan.

Olowoyeye, G.B., Ogunlade, B.O. (2015). Instructional Materials and Ubiquitous Computing Technology: The Strong Bonds to Effective Learning in Nigerian Secondary Education. International Journal of Liberal Arts and Social Sciences, 3 (8), 92-101.

Owuamanam, T. O. (2005) The role of counselor and other school staff in providing quality education in Nigerian schools. Nigerian Guide for Guidance and Advice, 10, 1, 12 - 21.

Ramlogan, S., Raman, V. \& Sweet, J. (2014). 'Comparing two types of teaching: video compared to live instructional study in clinical periodontology ', European Journal of Education 18 (1), 31-38.

Sáez-López, J. M., Román-González, M., and Vázquez-Cano, E. (2016). Visual planning languages are integrated throughout the elementary school curriculum: A two-year course uses "Scratch" in five schools. Computers \& Education, 97, 129-141.

Taslibeyaz, E., Aydemir, M. and Karaman, S. (2017). 'Analysis of research trends in articles on the use of videos in medical education, Education and Information Technologies, 22(3), 873881.

Vijay, P.G. (2017). Technical and Vocational Education and Training (TVET) program in India for continuous development. Establishment Center.. www.educationinnovations.org

Yildirim, S., \& Kaban, A. (2010). An attitude of pre-service teachers with computer-based education. International Journal of Human Sciences, 7(2), 158-168

UNESCO shaping the future we want, UN Decade Education for Sustainable Development (2005-2014) Final Report. Paris.

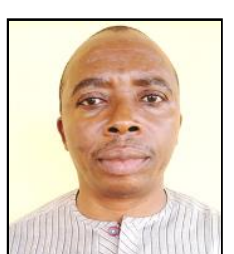

Bamidele Olusola Ogunlade had BSc. (Ed) in Technical Education. Master's and Ph.D. degrees in Educational Technology from Ekiti State University, Ado-Ekiti between 2005-2015 respectively. $\mathrm{He}$ is a Senior Lecturer at the Bamidele Olumilua University of Education, Science and Technology. Ikere Ekiti Nigeria.

His research interest is to solve learning problems with $21^{\text {st }}$-century skills. He has served as Instructional/Tutorial Facilitator and Project Supervisor at the National Open University of Nigeria (NOUN).

$\mathrm{He}$ is a registered member of the Teachers Registration Council of Nigeria(TRCN), Educational Media and Technology Association of Nigeria (EMTAN), Association for Innovative Technology Integration in Education (AITIE), and Educational Researchers and Evaluators of Nigeria (ASSEREN)

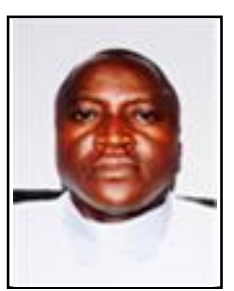

Samaila Benedict Bahago had B.Th. (Ed) in the Theology University of Jos. Master's degrees (M.Ed. 2008) and Ph.D. degree (2011) in Counseling and Educational Psychology from the University of Abuja. He is a Lecturer II at Veritas University Abuja. His study focuses on using 21st-century abilities to overcome learning challenges through counseling.

His study focuses on using 21st-century abilities to overcome learning challenges through counseling. He has served as a Rector at St. Mary's Polytechnic Suleja.

$\mathrm{He}$ is a Licensed and registered member of the Teachers Registration Council of Nigeria (TRCN), Association of Professional Counselors in Nigeria (APROCON), Counseling Association of Nigeria (CASSON).

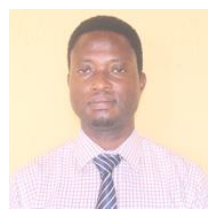

Aderemi Sunday Ogunmodede had BSc. (Ed) in Accounting Education. Master's degrees in Educational Technology from Ekiti State University, Ado-Ekiti, between 2015-2018. He is an Assistant Lecturer at the Bamidele Olumilua University of Education, Science and Technology. Ikere Ekiti Nigeria.

His research interest is to solve e-learning problems in the educational system in Nigeria and globally. He has a vast knowledge of IT, especially in remote learning.

$\mathrm{He}$ is a registered member of the Teachers Registration Council of Nigeria (TRCN), Educational Media and Technology Association of Nigeria (EMTAN), and Association for Innovative Technology Integration in Education (AITIE). 